\title{
The influence of Ecology on the Identity of a Child in Kashmera Sheth's
}

\section{Boys Without Names}

\author{
Faisal Lafee Alobeytha (Corresponding author)
}

Mafraq, Jordan

\section{Abdul Hamid Salim Al-Douhani}

Muscat, The Sultanate of Oman

\begin{abstract}
Victims of child labour trafficking endure chronic trauma where they often suffer from physical and psychological exploitation. This paper examined the role of ecology in the identities developments of the children before and during abducting and recruiting them as trafficked children. Kashmera Sheth's Boys Without Names (2010) was selected to be the sample of this study. Bronfenbrenner's Ecological System Theory (1994) guided the theoretical framework. The findings of this article exhibited that (i) ecological structures contribute to the identity development of children, (ii) ecological nests paved the road for the traffickers to abduct and recruit their victims, (iii) traffickers at all times intend to abolish and rape the identity of the victims and (iv) young adult literature is an appropriate sort of literature for raising the awareness of child trafficking
\end{abstract}

Keywords:

child labour trafficking, ecology, identity, traffickers, young adult literature.

Article Received: 18 October 2020, Revised: 3 November 2020, Accepted: 24 December 2020

\section{Introduction}

Servitude did not end with the cancellation of its canon in the 19th century (Craig, 2017), but it still harms people everywhere. Its name was changed to human trafficking (Kara, 2017), and it takes various forms such as organ trafficking, prostitution, child soldier trafficking, child labour trafficking, involuntary domestic servitude, debt bondage and others. Children have not been far away from this trafficking where they are compelled to work in the sex industry, cultivation, mine as well as sweatshop (Chuang, 2010).

This paper discussed the identity as a chief theme in young adult literature (YAL). Kaplan (2005) explains that the goal of YAL is to search for the identity of teenagers in literature. The structures of the identities of young adult readers (YARs) are connected to the YAL. Reading novels of young adults may affect the identities of those readers due to the interactions between the YARs and the texts. Engles and Kory (2013) see that the identity "often depicts self-conscious protagonists coming to a new conception of who and what they are" (p. 55) The identity is frequently influenced by some variables such as family, schools, peers, religion, standards, culture, government and others.
This study aimed to examine the influence of the ecology on the identities of the children before and during being trafficked in Kashmera Sheth's Boys Without Names.

\section{Literature Review}

Numerous scholars have studied human trafficking in literature. Jehlen (1990), for example, reviewed the trafficking of children from Africa to the United States of America. He identified the framework of the normal relevance between White and Black people in Mark Twain's Pudd'nhead Wilson (1876) where Blacks were dehumanized and sold in American and European markets as commodities. Furthermore, in her criticizing the film of Beatriz Flores Silva's En La Puta Vida (2001), Nubla (2009) also discussed the issue of the sex industry in the Philippines as it appeared in the Filipino American's literature. Her samples were Han Ong's Disinherited (1968) and Henson's Comfort Woman: A Slave of Destiny (1996). Stachura (2012) clarified how the weak economic situation pressurized several girls to work in prostitution. Additionally, in her discussion of James Joyce's Eveline, Reinares (2012) tackled the white slavery in Europe and how White women were betrayed and sold in 
sordid homes. Bickford (2012) examined the influence of sex trafficking tales on the readers and how they motivate their reactions. She inspected Patricia McCormick's Sold (2006) and James Levine's The Blue Notebook (2009), Bamisaye and Sotunsa (2019) discussed the experience of trafficked children in Boys Without Names. Alobeytha, Ismail and Shapii (2016) examined the framed story in the Boys Without Names by Kashmera Sheth. In contrast, some scholars also focused on child soldier trafficking, Hron (2008), for instance, discussed the image of the violence and cruelty that were used to torment the child soldiers in Iweala's Beasts of No Nation (2005). Coundouriotis (2010) also compared the novels of child soldier trafficking which were written before and after the 1990s and how they looked at child soldiers.

Unfortunately, most of the studies focused on human trafficking and ignored child trafficking. They also concentrated on sex and soldier trafficking and neglected other types of human trafficking such as labour, begging, and organic trafficking. There is a lack to study the relationship between the ecology and building the identities of trafficked children in YAL.

\section{Method}

This paper was a qualitative study that used Braun and Clarke's thematic approach (2006) to analyze the literary text. The sample of this study was Boys Without Names which was written by Kashmera Sheth in 2010. Bronfenbrenner's Ecological System Theory (1994) guided the framework of this study. This theory has five structures (a) Microsystem: it studies the impact of the surrounding environment (parents, schools and peers) on an individual, (b) Mesosystem: it studied the relationship between the microsystem elements and how it impacts on an individual, (c) Exosystem: it studies the indirect impact of the economic, political, educational and governmental systems on an individual, (d) Macrosystem: it studies the impact of culture, norms and law on the individual, (e) Chronosystem: it studies the impact of an event on the life of an individual for a long time. The following figure explained Bronfenbrenner's Ecological System Theory:

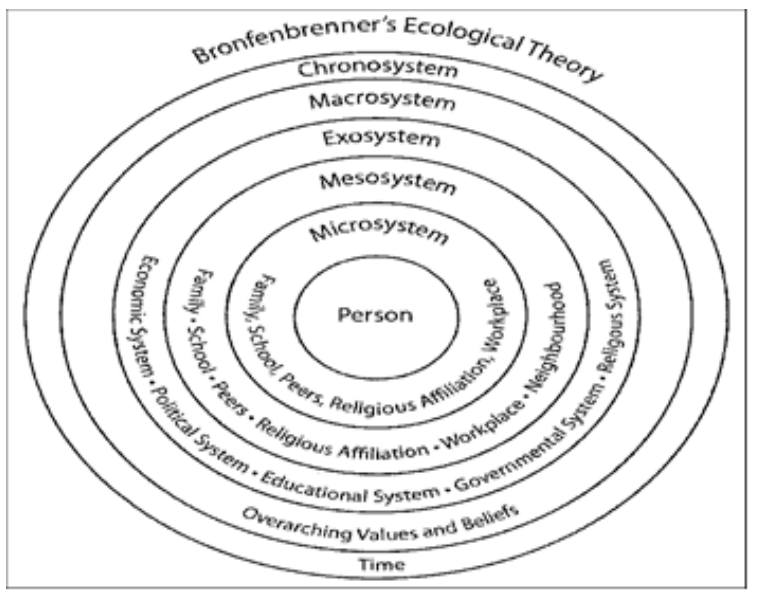

Figure 1. Bronfenbrenner's ecological system theory (1994)

\section{Discussion}

This paper centred on two periods (a) the identity of the hero Gopal (the hero of the novel) before being trafficked as a child worker and (b) the identity of Gopal as a trafficked child. The analysis was based on the fourth structures of Bronfenbrenner's EST: microsystem, exosystem, macrosystem and chronosystem. Unfortunately, the mesosystem was not covered in this study due to the shortage of data about the relationships between the microsystem members.

4.1 The identity of Gopal before being trafficked as a child labourer

\subsubsection{Microsystem}

This section examined the role of Microsystem (parents, school as well as peers) in building the identity of children through supporting their character with several doctrines such as virtue, 
patriotism, loyalty, altruism, honesty, and faith. Sheth (2010) highlighted a positive picture of Gopal's community where people respected each other. She highlighted the loyalty of Gopal's mother, Aia, to her friends and neighbours when she refused the probability of departure her village, "[i]t will be so lonely without our family and friends" (Sheth, 2010, p. 2). She expected the loneliness if she departed her village since she was not able to imagine her life without her extended family and friends. She did not want to experience nostalgia since this sincere feeling could cause a lot of pains to her. Therefore, she expected the worst if she left her village.

Not everyone fell nostalgia unless he or she has deep love towards his $\backslash$ her ecology. Some people who do not allocate their hearts and minds to serve their country will not have a feeling of nostalgia. Gopal's mother also raised her son to adore his village, and pay his loyalty to his people and lands. She realized that if Gopal had a loyalty to the country during his childhood, he could be an honest nationalist. She talked to her husband and son, "we can't leave our desh, the land of our forefathers" (Sheth, 2010, p. 1). She linked her existence to confirm her faithfulness to her homeland. Certainly, the basis of national identity may consist of norms, domestic symbols, conventions, and national experiences. These bases are rooted in any nation (Harrison \& Johnson, 2009). Therefore, Sheth concentrated on the idea of national identity which boosted the identity of an individual. If a child possesses the two identities (national and individual identities), his/ her self-esteem will be very high due to his\ her proud of the history and nation. Gopal's villagers were compelled to leave due to their miserable conditions (Sheth, 2010).

Indeed, Gopal's parents played a significant role in building his identity which helped him deal with diverse matters. His parents realized that Gopal was more likely to do his tasks and they could depend on him in their lives. Thus, they always shared their anxieties and ideas with him, Gopal clarified that "I'm eleven, and for the last three years Baba and Aai have told me about our troubles" (Sheth, 2010, p. 1-2). His parents placed him as the breadwinner of the family. It seems that they preferred to share their suffering with their child early since children in poor countries are working to assist their families. Gopal demonstrated the job of his father as a worker at a quarry splitting stones and his mother as a porter in the train station. Gopal explained his family's condition, “.... and we're poor. As poor as the pipul tree is bare in the autumn" (Sheth, 2010, p. 3). Gopal's state was similar to the tree which lost its leaves in autumn. The novelist used a simile to depict strong imageries of poverty. The tree symbolized Gopal's family who lost their land, money and other things. Poverty pushed underprivileged Ama to contemplate to avoid feeling disheartened. She resorted to it in the hope that they would live a good life in the future. Thus, Ama (Gopal's mother) depicted the daydream as "building air palace" (Sheth, 2010, p. 56).

In addition to the role of his parents as an essential element in the microsystem, Gopal's relationship with his peers contributed to his character's growth. Mohan and Shiva (Gopal's friends) improved Gopal's optimistic morals. Gopal's responses to this honourable friendship looked apparent when he left for Mumbai. He rejected to inform them about his immigration. He was perplexed of lying to them since his immigration was a secret matter and he did not need to reveal this matter. Sheth emphasized a new lesson about lying as an immoral habit and it ought to be avoided since lying extinguished the good identity of a person. Liars lose the respect and trust of others. Lying has a horrible role in cutting off the bonds of harmony between friends where they do not trust each other.

Furthermore, school (one of the microsystem's components) contributed to building Gopal's identity. Thus, Sheth considered education a key factor that could rescue the children from their present status. She understood that sending children to schools was an indispensable stride in defeating child labour trafficking. Then, they got easy goals for the traffickers who hired them in 
their ranches, workshops and national services. Sheth talked about the role of the school many times to drive the concerns of YARs to the significance of education in their identities development. During the dialogue between the parents of Gopal, his father informed his mother, " Gopal is smart, and we must send him to school so he has a future" (Sheth, 2010, p. 6). His parents wanted him to live a better life than theirs. Accordingly, they found in schooling a door for an optimistic future for their children. Gopal's father anticipated a better future for his children if they got a good education and he understood that staying in their poor village might bring more pains to his family. Therefore, he decided to migrate to Mumbai. He informed his wife, “ besides, the children will get a much better education there" (Sheth, 2010, p. 7). Overall, the role of microsystem contributed to the emergence of child trafficking especial the lack of education while Gopal's parents played a key role in the building of his identity which resisted the traffickers as it will be discussed later.

\subsubsection{Exosystem}

This section investigated the method of the moneylender (Exosystem) in destroying the identity of children. Poverty is considered one of the key causes of the appearance of child trafficking (Loomba, 2017). Thus, poverty disturbs nearly every aspect of the identity development of children. Sheth presented an obvious picture of Gopal's family who underwent poverty and ran their job simply to live under the awful work circumstances as it was clarified in the previous section (microsystem). Gopal displayed how the village dwellers felt pain from their luckless conditions. He portrayed their condition by saying, " like many other villagers, we have lost our land and can't grow crops" (Sheth, 2010, p. 3).

There were tremendous figures of farmers residing in India under debt oppression. Those farmers were subordinated to pay off loans of one of their families. Thus, the moneylenders would benefit from employing whole families that tethered to debt that cannot be paid off (Fraser,
2016). Due to the low cost of the crop as mentioned by Gopal, his father did not have money to buy fertilizers as well as seeds for his ranch. Hence, he ought to borrow a little amount of money from the moneylenders in his village at a high-interest rate. This borrowing was not easy for him who suffered the maltreatment of the moneylender which directed him to get low selfesteem.

Sheth illustrated how the tyrannical bonds between the moneylenders and fathers contributed to the appearance of the child as well as bonded labour trafficking. The moneylender threatened Gopal's father to send his son to work under his control as a forced labourer if he would not pay the debt on time. He informed his wife that the moneylender intended to enslave Gopal for unknown years. The moneylender ordered Gopal's father "[b]ring your son with you. He can work and help you pay off the debt". (Sheth, 2010, p. 6). Due to his elevated self-esteem and powerful identity, Gopal's father declined to surrender to the moneylender. Some farmers, on the other hand, agreed to subjugate to the moneylender who disregarded them and put their identity and selfrespect at the rock bottom.

Human labour trafficking is similar to the shark term that was used by Shakespeare in his play The Merchant of Venice. Shark means moneylender who gives money to poor individuals at irrational amounts of interest ( Arnold \& Booker, 2013). Hel She reflects one of the numerous pushing variables that pressure rustics to depart their households to find jobs in cities or overseas. Gopal's father was one of those farmers who chose to depart the home and went to Mumbai to look for a job otherwise, he ought to work in the moneylender's farms as forced labourers (Sheth, 2010). The household of Gopal ought to select one of two alternatives: to stay or leave the village. Thus, Sheth began his novel by declaring the father of Gopal, "[w]e stay, we starve," (Sheth, 2010 , p. 1). Thus, it was awkward to ignore the effect of the loan shark on Gopal where the moneylender's materialism was the cause underneath Gopal's catastrophe in abandoning his 
town and being trafficked in Mumbai.

Therefore, being slaves in Gopal's village never promoted the dignity of needy farmers where some favoured death instead of being slaves. Regrettably, several of these farmers (as the father of Shiva) resorted to suicide. Gopal explained the causes of the suicide, "I think of Shiva's baba, who killed himself last year because he couldn't pay his debt" (Sheth, 2010, p. 12-13). They selected death because they felt that their lives became useless and they could not be the breadwinners of their families. Indeed, committing suicide due to moneylenders is prevalent among Indian farmers (Mishra, 2014)

\subsubsection{Macrosystem and Chronosystem}

This section examined how the macrosystem combated destitution to prevent taking advantage of children from being trafficked labourers. It also tackled how chronic poverty influenced the identity of the individual. Chuang (2006) tackled how poverty drove people to immigrate and how they met the traffickers, he cited that "The problem of trafficking begins not with the traffickers themselves, but with the conditions that caused their victims to migrate under circumstances rendering them vulnerable to exploitation" (p.140). Okyere (2017) described how globalization contributed to the emergence of child trafficking. He talked about how destitution was the cause of child trafficking in Ghana. He also refused America's policy of imposing economic penalties on Ghana where these boycotts led to a growth in child trafficking rates.

Despite the role of the macrosystem (the government) in decreasing the level of poverty in overpopulated countries like India, China, and others, the rate of child trafficking was high. The size of the destitution was still exceedingly astounding and it caused social illness, weak education and bad health services in some countries like India (Jordan, 2004; Prabhakaran, Jeemon \& Reddy, 2013). Therefore, child trafficking was an inevitable result. Sheth underlined the influence of chronic poverty on farmers which produced two types of people: rich individuals (moneylenders) and poor individuals (the farmers). The former looked down to the later and considered them filthy, irresponsible and unusable. Furthermore, they predicted the failure of the farmers in their lives unless they were led by them. This idea was unacceptable by Gopal's family when they challenged the authority of the moneylender and migrated to Mumbai. Gopal's father insisted on departing the village.

Sheth (2010) disclosed the role of the macrosystem ( government) in its struggle against the chronic of a money-lending policy which led to the emergence of child labour trafficking in India. The Indian government failed to prevent moneylenders from employing children in the farms of moneylenders. Gopal predicted that the moneylender might know about the escaping of Gopal's family, he "might go to the police to complain. Baba might end up in prison" (Sheth, 2010 , p. 24). This confirms that the government did not try to prevent moneylenders from abusing farmers. Therefore, the farmers deserted their village to the big cities to search for a job and escape from the bonded labour traffickers. These cities were considered a pull factor that enticed needy families while their original villages were the push factors.

\subsection{Gopal's Identity as a Trafficked Child}

\section{Labourer}

This section analyzed the effect of the traffickers on the Gopal's identity in the frame factory. Sheth refused the notion that trafficked children could be depressed and incapable to escape themselves from their place. Thus, she created the great character of Gopal to be an example of a boy who has high self-esteem. Sheth (2010) focused on two sorts of characters (a) the stable strong character that was stood for Gopal and (b) the stressful defeated characters that stand for his trafficked peers. Hence, this section displayed the method of Gopal in dealing with his peers. It also shed light on how Gopal secured his unique identity in front of his manager Scar (the boss of the frame factory).

\subsubsection{Microsystem and Macrosystem}

This section focused on how microsystem (peers and parents) deceived children to be abducted and 
recruited as trafficked children. A deception is an act that provides an individual with incorrect data (Schwardmann \& Van der Weele, 2016). The temptation of good work, excellent education or a comfortable life are the tools used to deceive children to enslave them as trafficked children.

The traffickers pretended that they owned the ability to get a job for the broods (Abidin \& Nur, 2017; Kaufka Walts, 2017). The victims believed that their future might be improved if they followed the instructions of the human traffickers. Therefore, they agreed to travel from their homeland to get jobs before they understood that they were deceived and turn out to be slaves. The victimized children faced a limited or single selection after they discovered that they were betrayed. This selection was the acceptance of the present condition as trafficked children (Kaufka Walts, 2017). If not, they would be penalized and murdered.

Sheth (2010) used a frame story to narrate the story of the trafficked children to cover the child trafficking forms and method. Therefore, readers can see the subject from diverse positions. Aframe story is introduced as "secondary story or several other stories within the main story" (Alobeytha, Ismail \& Shapii, 2016). Sheth exhibited the procedures that were used by traffickers to betray the protagonists by bringing up the stories of trafficked protagonists who were deceived by working in the factory. For example, Roshan (Night Chatterer) was one of the protagonists who narrated his story. He was around eight-years-old when his father asked some strange people to take him to work in the city. Those strangers betrayed his father by false promise, Roshan narrated that:

One day some people came to us with a meme-megaphone and ann-ann-announced that they would find us jobs in the big city that would pay well. My-my baba asked them how much I would make and they said, 'Yoyo-your son will make enough to feed your family and he will attend school and have a city ad- adventure (Sheth, 2010, p. 206).

Paradoxically, despite the traffickers encouraged people to send their children to the city by using a loudspeaker, the police officers did not investigate the matter or even asked the traffickers about their businesses. Police officers (Macrosystem) were supposed to know the details about the traffickers. The microsystem (parents) did not try to ask about their children's works and their salaries. This behaviour of the police and parents influenced the identity of those trafficked children who hesitated to trust the others.

The traffickers assume that an individual who betrays a child can be one of his $\backslash$ her peers. To avoid doubt of a community and police, a female child trafficker, for example, will talk to another female child to guide her to the traffickers. Sheth exhibited how traffickers used peers ( Microsystem) to deceive and appeal the children to have jobs in the factory. Traffickers sent a child trafficker Jatin to attract and convince Gopal and other children to go to the factory. Jatin pretended that he was closed to his uncle who was the landlord of a factory. He could convince him to employ Gopal in this factory. Jatin stated, "You can work for my uncle" (Sheth, 2010, p.109). The intelligence of Gopal never helped himself avoid the trickery of Jatin because he was anxious and keen to have work. Getting work for Gopal was impossible and like a mirage. His distressing about his household and the loss of his father pressurized Gopal to ignore his worrying about Jatin's conduct in the hope that he could get a job. Gopal told himself, “ as I am talking to Aai, I think of Jatin's sleek hair. For some strange reason, it makes me uncomfortable" (Sheth, 2010, p. 97).

Despite the aptitude of Jatin in betraying the victims, Gopal felt that there was a doubt in Jatin's complaining about his needing money. His dresses did not indicate that he was poor. Gopal observed that Jatin's dress was good. This confusion pressed him to confess that he could not believe Jatin. Gopal informed his mum, "[n]o, actually he was friendly. But still...I didn't trust him. Maybe because he is a stranger" (Sheth, 2010, p. 97).

Gopal betrayed himself when he attempted to 
rationalize the reason that pushed Jatin to look for money. He thought that one of Jatin's relatives was sick. He might also trick himself (selfdeception) when he believed that the ethics and principles of the children were the same. He neglected all the qualms around Jatin's conduct and activities before soaring to the goal that was having a job. Then, he impugned himself for the resolution that ran him to be trafficked. He decided to be more cautious when he treated strangers, Gopal stated that "Oh, I wish I hadn't been so anxious to find work" (Sheth, 2010, p. 122-123). This incident was the springboard that taught Gopal how to be cautious with methods of releasing the other trafficked children from the sweatshop. He cited:" [i]f my impatience and stupidity have brought me here, then the only way out is to have patience and cunning" (Sheth, 2010, p. 131). Overall, both the microsystem and macrosystem contribute to the emergence of child trafficking in many countries.

\subsubsection{Chronosystem}

This section analyzed the impact of chronic child trafficking on the identity of trafficked protagonists and it focused on the importance of names in building the identities of children. A name has a precise meaning and a significant positive or undesirable impression on the character of a person (Krstić, 2017) since it influences the development of the identity and behaviour of the individual (Laham, Koval \& Alter, 2012). Sheth focused on the quandaries of those protagonists who were unable to utter their real names due to the orders of their boss who declared "[n]o names are allowed in this place" (Sheth, 2010, p. 121). In his actions as a dictator, Scar remoted these trafficked children from their actual identities and their histories to simply erase their sense of identities.

Gopal comprehended the significance of names in rebirthing the children's feelings of identity. His goal from recognizing the actual names of the trafficked children was as he confirmed, " If I want the group's help I must know their names and make them my friends" (Sheth, 2010, p.149). Gopal failed to distinguish their names when he requested them to tell their names. Thus, he gave names for them based on their physical features, for example, Rocking Boy and Thick Finger. Gopal stated that:

What's your name? He gives me a blank look that is filled with sadness before he lowers his gaze. I sigh. "You do have a name, don't you?" Rocking Boy looks in the direction of the ladder. He nods. "Tell me, or else I will call you Rocking Boy (Sheth, 2010, p. 138).

Those victims were afraid of recalling their names due to the chronic servitude that they lived and the cruel punishments of Scar (the boss) if he knew that children uttered their names. During the debating between Gopal and his boss, it was obvious that the boss intended to abolish the identity of the trafficked children. Gopal stated: " My name is Gopal," I say. Scar fixes his stare on me. "So? You're working for me. I'll call you cockroach if I want" (Sheth, 2010, p. 121).

As soon as the children realized the importance of the names in their life, they shared their experiences and this sharing was a sign of the growth of their identities. Some of the victims' identities were recognized by their silence, thus, their identities should be stimulated to let them feel their presence, or announce their desires. The soundless identity of the victims had emerged from the ferocity that they were exposed to. Gopal inspired his colleagues to share their thoughts that supported them in constructing their identities. He utilized his endowment in narrating tales to retrieve the identities of other peers. His tales continuously targeted to criticize the present condition in the factory and boost them to do anything to escape from this servitude. He told the tale of calves and the bull, he confessed that " this is a story I have never heard or told before and I make it up as I go along" (Sheth, 2010, p. 225). He utilized it as a metaphor to reveal the child labourers' situations and their tussles with Scare. The indolent bull, Giant, embodied the boss whereas the six calves in the factory embodied the six trafficked children. The tale of calves and bull highlighted the consequences of killing real identities. It also inspired the victims to believe 
the possibility of escaping from this sweatshop and returning their identities.

In addition to the importance of the names in the lives of children, traffickers often lead trafficked people into the status of silence by numerous kinds of torments (Crawford \& Kaufman, 2008). Sheth highlighted the influence of chronic violence on the identities of the children. It is known that chronic violence towards the victims is one of the elements that deconstructs their identities (Barnard 2014; Ali, Ali \& Abbas, 2017). The policy of vehemence produced a state of doubt and an absence of self-confidence that controlled the common ecology between the microsystem sets (the peers). The trafficker Scar as a materialistic stingy person who allocated his life to gather money and tyrannized the other lacked the ethics that controlled his actions and conducts towards his victims. Scar never hesitated to misuse, steal, insult and coerce the children to obtain some profits. Hence, his extreme meanness and materialistic character made the children disgust at him. Sheth described the character of Scar by Gopal's statement, "except for insults, Scar never gives anything for free" (Sheth, 2010, p. 157). Thus, the vehemence and its menace were the weapons that Scar used to control the children. This pressurized Gopal to announce that Scar never merited to be a human being as he vindicated that " He doesn't even deserve beast behind his name" (Sheth, 2010, p. 114).

In most cases, trafficked people acquire the traits and behaviours of the traffickers before being traffickers. Therefore, their innocent identities may convert to the identities of traffickers or slaves through their being trafficked children.

The outcomes of staying in the sweatshop for a long time disregarded and depressed the identities of the trafficked children. Those victims praised Scar to get his satisfaction. In contrast, the superpower (Scar) blamed the victims and rebuked them for their conduct, performance and activities. Gopal cited, "Stay there, you rat" (Sheth, 2010, p. 113).

The behaviour and treatment of Scar succeeded in abolishing the identities of the victims except for the identity of Gopal who resisted Scar. Gopal did not give in to Scar despite the depression of his friends who capitulated to Scar and agreed to be slaves since they thought that the road to liberty was awkward. Gopal established his high selfesteem by expressing his desire in a hidden when Scar spoke to him, “ if you do a good job with these higher-quality frames, you will be rewarded," he says. I don't want to be rewarded. All I want is freedom" (Sheth, 2010, p. 257). The reason behind the strong identity of Gopal went back to his past microsystem (parents, siblings, peers, worship place, and school) which encouraged him to fight the new situation and to protect his identity. In contrast, the identities of the other six protagonists in the sweatshop were inactive and they accepted the present condition because they feared their history and Scar. Some of those protagonists were orphans or destitute. Thus, nothing motivated them to escape from the sweatshop. Gray Cloud (one of the protagonists) investigated his destiny after fleeing from the sweatshop, “[w]hat if one of them doesn't have a family?" (Sheth, 2010, p. 225).

Despite the critical conditions and the cruelty of the boss, Gopal adhered to his morals even in the duskiest of periods that he passed. Gopal affirmed that "Scar and Thick Fingers can't stop me from doing that - or from planning my escape" (Sheth, 2010, p. 123). He was enthusiastic to escape and get his freedom. He continually stimulated the other peers to keep in mind their freedom and never think of being egotistic. He found several opportunities to escape alone, but he refused to do it because he wanted freedom for his peers. He connected the word rescue with the word us or our thirteen times in the novel, for example, he stated, "I again think about our rescue" (Sheth, 2010, p. 270). Overall, the chronic violence played a major role that contributed to change the identity of the trafficked children except for Gopal who resisted this alteration.

\section{Conclusion}

Novelists have raised the awareness of child labour trafficking between readers. Thus, it also a good strategy to use this literature to teach moral 
lessons. The structure of this paper based on Bronfenbrenner's ecology theory (1994) in analyzing the novel Boys Without Names (2010). This study concluded that traffickers aimed to destroy the identity of their victims to enslave them for good, the role of ecology contributes to constructing or deconstructing the identities of the trafficked children, it is so necessary to rebirth the identities of trafficked children by reminding them of their histories, violence and deception are used to subjugate the trafficked children by the traffickers, and it is very attractive to discuss the issue of young adults in their literature. This study limited itself to the YAL, it also focused on the identity of the victims and it focused on one type of child trafficking. This study suggests that future studies can focus on the identity of the traffickers. They can focus on other sorts of child trafficking such as child begging, organ, sex, and soldier trafficking.

\section{References}

[1] Abidin, K., \& Nur, S. (2017). The determinant of human trafficking victim of woman and children. The Social Sciences, 12 (9), 1605-1610.

[2] Ali, M. A., Ali, M. V., \& Abbas, F. (2017). Hidden hazardous child labor as a complex human rights phenomenon: A case study of child labor in Pakistan's brick-making industry. Cogent Social Sciences, 3(1), 123.

[3] Alobeytha, F. Ismail, S, \& Shapii, A. (2016). The Use of frame story in Kashmira Sheth's Boys without Names. Advances in Language and Literary Studies, 7(5), 105111.

[4] Arnold, L. G., \& Booker, B. (2013). Good intentions pave the way to... the local moneylender. Economics Letters, 118(3), 466-469.

[5] Barnard, A. (2014). The second chance they deserve: Vacating convictions of sex trafficking victims. Columbia Law Review, 114(6), 1463-1501. Retrieved from http://www.jstor.org.eserv.uum.edu.my/stab le/23932264.

[6] Bickford, M.(2012).We all like to think we've saved somebody: Sex trafficking in Literature. Journal of International Women's Studies, 13(3) 126-136.

[7] Braun, V., \& Clarke, V. (2006). Using thematic analysis in psychology. Qualitative Research in Psychology, 3(2), 77-101.

[8] Bronfenbrenner, U. (1994). Ecological models of human development. Readings on the Development of Children, 2(1), 3743.

[9] Chuang, J. (2006). Beyond a snapshot: Preventing human trafficking in the global economy. Indiana Journal of Global Legal Studies, 13(1), 137-163.

[10] Chuang, J. (2010). Rescuing trafficking from ideological capture: Prostitution reform and anti-trafficking law and policy. University of Pennsylvania Law Review, 158(6), 1655-1728. Retrieved from http://www.jstor.org.eserv.uum.edu.my/stab le/25682362.

[11] Coundouriotis, E. (2010). The child soldier narrative and the problem of arrested historicization .Journal of Human Rights, 9:191-206.

[12] Craig, G. (2017). The UK's modern slavery legislation: An early assessment of progress. Social Inclusion, 5(2), 16-27.

[13] Crawford, M., \& Kaufman, M. R. (2008). Sex trafficking in Nepal: Survivor characteristics and long-term outcomes. Violence Against Women, 14(8), 905-916.

[14] Engles, T., \& Kory, F. (2013). Incarceration, identity formation and race in young adult literature: The case of "monster" versus "hole in my life" The English Journal, 102(4), 53-58. Retrieved from http://www.jstor.org.www.ezplib.ukm.my/st able/23365350

[15] Fraser, C. (2016). An analysis of the emerging role of social media in human trafficking: Examples from labour and human organ trading. International Journal 
of Development Issues, 15(2), 98-112.

[16] Harrison, C. E., \& Johnson, A. (2009). Introduction: Science and national identity. Osiris, 24(1), 1-14.

[17] Hron, M.(2008).Orana-azunwa: The figure of the child in third-generation Nigerian novels. Research in African Literatures, 39 (2): 27-48.

[18] Jehlen, M. (1990). The ties that bind: Race and sex in Pudd'nhead Wilson. American Literary History, 2, (Spring) 39-55.

[19] Jordan, G. (2004). The causes of poverty cultural vs. structural: Can there be a synthesis. Perspectives in Public Affairs, 1(1), 18-34.

[20] Kaplan, J. S. (2005). Young adult literature in the 21st century: Moving beyond traditional constraints and conventions. Retrieved from: https://scholar.lib.vt.edu/ejournals/ALAN/v 32n2/kaplan.pdf

[21] Kara, S. (2017). Perspectives on human trafficking and modern forms of slavery. Social Inclusion, 5(2), 1-2.

[22] Kaufka Walts, K. (2017). Child labor trafficking in the United States: A hidden crime. Social Inclusion, 5(2), 59-68.

[23] Krstić, P. (2017). Thinking identity with difference: Society and theory. Filozofija I Društvo, XXVIII (1),136-152.

[24] Laham, S. M., Koval, P., \& Alter, A. L. (2012). The name-pronunciation effect: Why people like Mr. Smith more than Mr. Colquhoun. Journal of Experimental Social Psychology, 48(3), 752-756.

[25] Loomba, A. (2017). Reconstructing lives: transformative services for human trafficking survivors. Journal of Services Marketing,31(4/5),373-384. Retrieved from : $\quad$ https://doi.org/10.1108/JSM-06-20160228

[26] Mishra, S. (2014). Farmers' suicides in
India, 1995-2012: Measurement and interpretation. Asia Research Centre Working Paper, 62. Retrieved From: http://www.ask-

force.org/web/HerbizideTol/Mishra-

Farmers-Suicides-India-1999-2012.pdf.

[27] Nubla, G. (2009). Innocence and the child of sex tourism in Filipino/American literature and culture. Rocky Mountain Review, 63,(Fall). 233-240.

[28] Okyere, S. (2017). Shock and Awe: A critique of the Ghana-centric child trafficking discourse. Anti-Trafficking Review,9 (1), 92-105.

[29] Prabhakaran, D., Jeemon, P., \& Reddy, K. S. (2013). Commentary: Poverty and cardiovascular disease in India: Do we need more evidence for action? International Journal of Epidemiology, 42(5), 1431-1435.

[30] Reinares, L.B. (2012). Commodified anatomies: Disposable women in postcolonial narratives of sexual trafficking/abduction.(Doctoral dissertation), Georgia State University, Atlanta, GA.

[31] Schwardmann, P., \& Van der Weele, J. J. (2016). Deception and self-deception. Retrieved from : https://rationality-andcompetition.de/wpcontent/uploads/discussion_paper/25.pdf

[32] Sebenius, J. K. (2017). BATNAs in negotiation: Common errors and three kinds of "no". Negotiation Journal, 33(2), 89-99.

[33] Sheth, K. (2010). Boys Without Names. NewYork, NY: Balzer + Bray ,Harber Collins.

[34] Stachura, M. (2012). An inhospitable world: The post-national imaginary in Latin American novel and film, 2000--2010. (Doctoral dissertation). University of Virginia, Virginia,VA 